Experience Report

\title{
Instrument of student assessment based on nursing managerial competences
}

\author{
Instrumento de avaliação do aluno com base nas competências gerenciais do enfermeiro
}

Instrumento de evaluación del alumno con base en las competencias gerenciales del enfermero

\begin{abstract}
When the students conclude the Curricular Training on Nursing Management discipline from the Professional Guidance Department at USP School of Nursing (EE-USP), they answer a self-assessment which scores from zero to ten the trainee program and a also participates in a group assessment, carried out by the professor and nurses from the units, practice fields. In this process, it was applied an instrument aiming at measuring students performance concerning managerial contents. With the purpose of accompanying students' background development according to the Pedagogical-Political Project by EE-USP, aiming at a meaningful learning that minimizes the theory/practice dichotomy, a new instrument was developed to assess students having nursing managerial competences as baseline. This study aims at describing the experience of building up an instrument for students assessment related to the nursing managerial competences. This paper has the purpose of reporting the following prognosticators: planning, decision-taking, supervision, human resource management, material resource management, information system, interpersonal relationship, responsibility, commitment and case study.
\end{abstract}

Keywords: Performance assessment, Competence-based education; Nursing students

\section{RESUMO}

Ao concluir a disciplina Estágio Curricular em Administração em Enfermagem do Departamento de Orientação Profissional da Escola de Enfermagem da USP (EE-USP), o aluno realiza uma auto-avaliação, atribuindo notas de zero a dez ao estágio e participa da avaliação conjunta, realizada pelo docente e enfermeiros das unidades, campos de prática. Nesse processo, empregava-se um instrumento com a finalidade de mensurar o desempenho do discente, a partir dos conteúdos de administração. Buscando acompanhar a formação do aluno com base no Projeto Político Pedagógico da EE-USP, visando uma aprendizagem significativa que minimize a dicotomia teoria/prática, elaborouse um novo instrumento de avaliação pautado nas competências gerenciais do enfermeiro. Este trabalho tem por objetivo relatar a experiência da construção de um instrumento de avaliação discente, considerando os seguintes prognosticadores: planejamento, tomada de decisão, supervisão, administração de recursos humanos, administração de recursos materiais, sistema de informação, relacionamento interpessoal, responsabilidade, envolvimento e estudo de caso.

Descritores: Avaliação de desempenho; Educação baseada em competência; Estudantes de enfermagem

\section{RESUMEN}

Al concluir la disciplina Práctica Curricular de Administración en Enfermería del Departamento de Orientación Profesional de la Escuela de Enfermería de la USP (EE-USP), el alumno realiza una auto-evaluación atribuyendo notas de cero a diez a las prácticas y participa de la evaluación conjunta, realizada por el docente y enfermeros de las unidades, campos de práctica. En este proceso, era empleado un instrumento observando y midiendo el desempeño del alumno a partir de los contenidos de administración. Buscando acompañar la formación del alumno fundamentado en el Proyecto Político Pedagógico de la EE-USP, observando un aprendizaje significativo que minimice la dicotomía teoría/ práctica fue elaborado un nuevo instrumento capaz de evaluar las competencias gerenciales del enfermero. Este trabajo tiene por objetivo relatar la experiencia de la construcción de un instrumento de evaluación del alumno considerando los siguientes pronosticadores: planificación, toma de decisión, supervisión, administración de recursos humanos, administración de recursos materiales, sistema de información, relacionamiento interpersonal, responsabilidad, desarrollo y estudio de caso.

Descriptores: Evaluación del rendimiento de empleados; Educación basada en competencias; Estudiantes de enfermería

${ }^{1}$ Ph.D., Professor at the Professional Guidance Department of the Nursing School at Escola de Enfermagem da Universidade de São Paulo - USP - São Paulo, (SP), Brazil.

2 Associate Professor of the Professional Guidance Department at Escola de Enfermagem da Universidade de São Paulo - USP - São Paulo, (SP), Brazil. 


\section{INTRODUCTION}

The Professional Guidance Department (PGD), in compliance with the missions and guidelines of the Nursing School of the São Paulo University (EE-USP) has the purpose of contributing to the scientifical-technical and ethical-political formation of the student for proper nursing practice in the subject areas of history and legislation, ethics, research and nursing management.

The Curricular Training discipline is ministered in the eighth semester of the undergraduate course, in which the students opt to have an internship in one of the four departments in the school. In the PGD, it is named Syllabus Training on Nursing Management, with a 315-hour workload, divided into 288 hours of internship (practice field) and 27 theoretical hours.

The internship objectives are: developing the nursing management process practice in the field, based on the following competences: knowing how to recognize, how to do, how to be, how to cope, which were acquired throughout the undergraduate studies; exercising the role of nursing manager in nursing services management and developing autonomy and safety for the equal insertion in the different multiprofessional groups.

In this context, the search process relies on the students. The professor is liable to stimulate and urge this search, the learning goal achievement and the development of competences. It is imperative to recognize that the performance throughout the activities depends on the student's individual effort and their interaction with others. Therefore, it is interdependent on each person's skills ${ }^{(1)}$.

It should be pointed out that, in this discipline, the students develop a case study, whose topic is selected from a problem-situation detected in the practice field. Afterwards, they propose, implement and evaluate intervention, showing it to the professor by means of a report.

At the end of the discipline, until 2004, the student performance assessment was performed by means of an instrument containing ten prognosticators, in a zero to ten scale. The students would perform their selfassessments and participate in the joint assessment carried out by the professor and nurses in the unit, the internship setting. This meeting enabled, besides student performance analysis, a discussion about their personal and professional growth, as well as their interpersonal relationships and teaching conditions offered by the field.

Throughout the years, there was questioning from students, professors and nurses regarding the assessment instrument, especially due to the fact that the items did not portray the requirements typical of the formation phase in which the students were.

Concomitantly, the PGD performed, on a weekly basis, discussion forums to restructure the disciplines founded on the theoretical construct of the competences and the four education pillars: knowing how to recognize, how to do, how to be and how to cope.

Thus, a new assessment instrument was developed with the purpose of minimizing the theory/practice dichotomy and provide the student with an assessment based on a significant learning-teaching active methodology.

This learning way is believed to determine subject changes, configuring the formation of a critical, reflexive professional who is aware of the social roles, an active subject in life and at work, according to the principles of the Public Health System ${ }^{(2)}$.

\section{THE PROCESS OF THE NURSE PROFESSIONAL FORMATION: CONTEMPORARY VISION}

The debates on the changes in Nursing education go back to two decades, and tackle the topic of the construction of critical pedagogical proposals, syllabuses integrated to each region reality, articulated with the community population interests, families, schools and other spaces, recognized as health promotion areas that go beyond the health systems ${ }^{(3)}$.

When it comes to the teaching-learning process, one of the challenges that Nursing has been facing stems to competent professional forming, committed to society and its health problems, looking for theory-practice articulation, in a critical view of reality, integrating the several aspects of the health problem, considering the individual complexity, the context in which they live and work.

Perrenoud $^{(4)}$ describes that the term competency shows multiple meanings and it may understood as an orchestration of cognitive and affective resources focused on fighting a set of complex situations.

Regarding the education competences, the author previously mentioned, explains that this word consists on the mobilization of cognitive resources that include the know-how, information, operational skills and after all, the intelligences for fighting and solving a number of situations, effectively and pertinently.

Vale and Guedes ${ }^{(3)}$ argue that in nursing, the term competency refers to the ability in knowing and acting in certain situations. It involves abilities to develop planning actions, implementation and assessment, requiring experience for quality performance. These authors point out the education pillars expressed in the National Curricular Guidelines, which enable the students to learn to learn, encompassing learning to be, to do, to cope and to recognize.

In this perspective, the essential learning relies on the four education pillars translated as learn to know, which consists of acquiring competence for comprehending, the domains of the knowledge instruments, that is, 
Tronchin DMR, Gonçalves VLM, Leite MMJ, Melleiro MM.

developing skills to build knowledge, exercising the thoughts, attention and memory, selecting the information which effectively may be put in a reality context, and be able to express by means of different languages; learn to do, with learning emphasis on the professional practice, that is, be able to put into practice the significant knowledge to the future practice; learning to live together points out the skill in discovering the other one, in developing solidary and cooperative projects, identified by the search of objectives in common. It implies developing self-awareness and self-esteem; finally, learning to be captures the idea that each individual should be fully prepared, body and soul, intelligence and sensibility, aesthetic sense and personal and ethical responsibility and spirituality in order to elaborate autonomous and critical thoughts, as well as formulating their own value judgments, so as to decide by themselves how to act in different life circumstances ${ }^{(5-6)}$.

Concerning professional competence, Deffune and Depresbiteres $^{(7)}$ employ the term, as the skill of using knowledge and abilities acquired for the practice of a professional situation. They add to competency, the ability in employing the knowledge to reach a goal; the skill in using knowledge, attitudes and acquired experiences to perform the social roles properly.

Confirming these ideas, Faustino and Egry ${ }^{(8)}$, point out that the term competence may be employed in a broader context, referring to the development of ethical, political, and technical competences, which enable the nurse to become, in the practice, the agent of social transformation. They recommend that the nurses employ an action-reflection tool. Also, they are urged to learn to recognize, to do, to be and to cope collectively, because these are the competences believed to be fundamental for every free and autonomous human being.

The curricular guidelines established by the Nursing major, present in in the Law of Guidelines and Bases ${ }^{(9)}$, state that the competences are fundamental aspects in the buildup of pedagogical projects and the syllabuses that will lead the formation of new professionals.

Understanding that learning needs to occur based on claims, here described, and in order to check whether the students in the Curricular Training on Nursing Management discipline are apt to synthesize the practice process in the technical, political and communicative dimension, a student assessment instrument was built based on the main guidelines of the Department and on the competences of knowing how to recognize, how to do, how to be and how to cope, developed throughout undergraduate course (Annex 1).

This paper aimed at reporting the experience of a professor group in developing a new student assessment instrument in the Curricular Training on Nursing Management discipline of EE-USP, focused on the nursing managerial competences.

\section{THE DEVELOPMENT OF THE ASSESSMENT INSTRUMENT}

The competence assessment understands that the student performance represents the mobilization of competences related to knowledge, abilities and attitudes. It aims at the student development, having as reference the professional competences to be acquired, not restricted to the performance results. However, based on it, strategies may enable the development of the necessary competences for the practice.

Seeking to learn what the students know how to do with the theoretical background acquired, what they wish to do, and identify what they need to know or which competences need to be developed, the present instrument was built (Annex), based on nursing managerial and ethical-political competences, in compliance with the PDG competences.

Hence, the instrument maintained the same number of items and the same zero to ten scale; the main change occurred regarding the item contents. Some were substituted so as to portray the internship requirements, and to represent, more objectively, the technical and attitude competences. An item was also included to assess the case study performed during the internship.

It should be clarified that the assessment technique was maintained, that is, it occurs during and at the end of the internship, with self assessment and nurse and professor assessment. The self assessment is seen to be indispensable in this process, and plays a key role due to the fact that the students being assessed have the opportunity to develop critical skills, thinking to themselves, reflecting about their limits and possibilities.

Thus, the central assessment idea, in this internship, is to use the new instrument as a means of problematization of the teaching-learning practice focused on two points: the skills of the student in doing, translating their performances and their willingness to learn.

\section{CONCLUSIONS}

The assessment evaluation proposed here has been applied for three years and there is the need of some more time to use this evaluation process, whose experience will allow to identify the elements which are likely to be modified for improvement. It goes with the claims from the contemporary references of competence and education.

It may be inferred that the student assessment has promoted responsibility and student commitment, in search of solutions to fight teaching-learning problems, 
configuring a participative action-reflection-action process, aimed at transforming the knowledge construction.

Having in mind that this competence assessment is a complex process, involving students, professors and field nurses, there is the need of broadening discussions

\section{REFERENCES}

1. Pereira ALF. As tendências pedagógicas e a prática educativa nas ciências da saúde. Cad Saude Publica $=$ Rep Public Health. 2003; 19(5): 1527-34.

2. Chirelli MQ, Mishima SM. A formação do enfermeiro crítico-reflexivo no curso de enfermagem da Faculdade de Medicina de Marília - FAMEMA. Rev Latinoam Enferm. 2003; 11(5): 574-84.

3. Vale EG, Guedes MVC. Competências e habilidades no ensino de administração em enfermagem à luz das diretrizes curriculares nacionais. Rev Bras Enferm. 2004; 57(4):475-8.

4. Perrenoud P. Dez novas competências para ensinar: convite à viagem. Porto Alegre: Artmed; 2000.192p.

5. Antunes C. Como desenvolver as competências na sala de aula. 5a ed. São Paulo: Vozes; 2004. 86p. and proceeding the analysis, both of the instrument and of this process development. Therefore, there will be a closer approximation to reality, identifying the competences to be reached by professors when ministering the discipline, seeking the formation of a skilled professional in care management.

6. Dellors J et al. Educação: um tesouro a descobrir. Relatório para a UNESCO da Comissão Internacional sobre Educação para o século XXI. 8a ed. São Paulo: Cortez; 2003. 288p.

7. Deffune D, Depresbiteres L. Competências, habilidade e currículos de educação profissional: crônicas e reflexões. São Paulo: Editora SENAC; 2000. 102p.

8. Faustino RLH, Egry EY. A formação da enfermeira na perspectiva da educação: reflexões e desafios para o futuro. Rev Esc Enferm USP. 2002; 36(4):332-7.

9. Brasil. Lei n. 9.394, de 20 de dezembro de 1996. Estabelece as diretrizes e bases da educação nacional. Lei de Diretrizes e Bases da Educação-LDB. [Internet] Brasília (DF), 1996 [citado 2007 Dez 12]. Disponível em http:// portal.mec.gov.br/secad/arquivos/pdf/ldb.pdf 


\section{ANNEX I \\ USPNURSING SCHOOL - CURRICULAR TRAINING ON NURSING MANAGEMENT ASSESSMENT INSTRUMENT}

Name of Student:

Nurse in Charge:

Institution/Unity:

Professor in Charge:

1. Planning: plans the health care and managerial plans according to the identified needs of the area/unit, coordinates the planned activities in function of deadlines and available resources, linking the results and the established objectives.

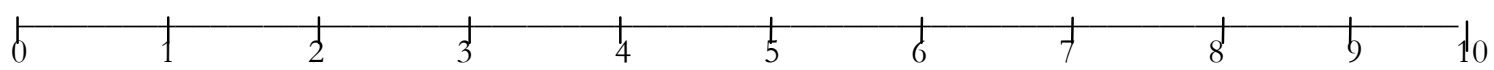

2. Decision-taking: identifies the problematic situations in the area/unit routine, analyzing the causes and consequences and proposes viable actions to solve them.

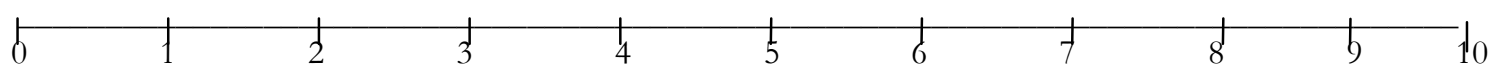

3. Supervision: analyzes the nursing team potentialities and limitations considering the working conditions. Searches educational strategies for immediate/punctual orientation and promotion of the nursing team development.

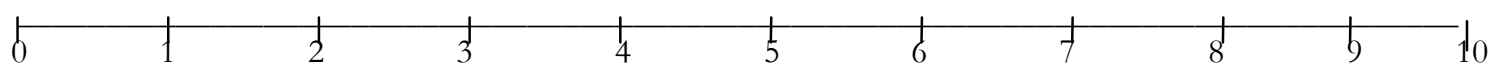

4. Human resources management: analyzes the quantitative and qualitative aspects of the nursing team in the area/unit, linking them to the criteria of daily and monthly employee distribution.

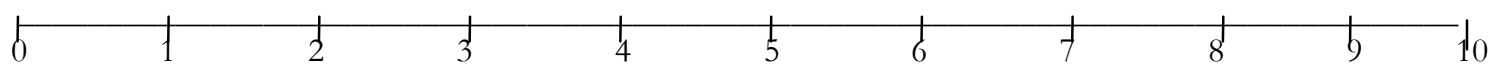

5. Material resources management: analyzes the activities of prediction, acquisition, provision, control and evaluation of managerial flow of material resources in the area/unit.

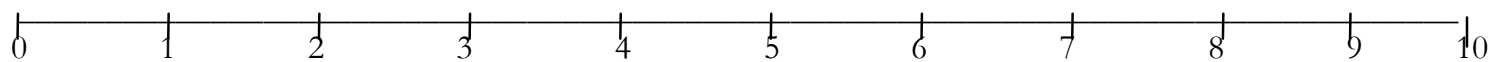

6. Information system: recognizes the means and instruments of the information flow, interpreting the process effectiveness in the communication process in the area/unit.

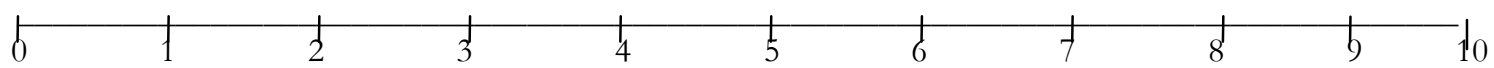

7. Interpersonal relationship: interacts with the clients, families and professionals, being understood. Respects the individuality of people, being able to identify conflict situations, proposing negotiation strategies. It is collaborative in the development of team work..

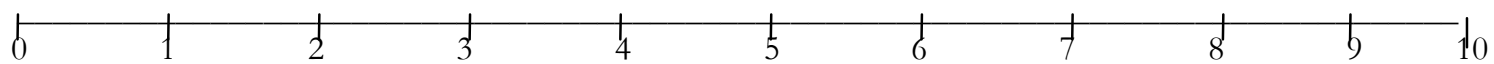

8. Responsibility: assumes ethical-legal commitment in the practice activity. Is aware of the competences that should be used in the unit and the technical-scientific knowledge. Is assiduous and punctual.

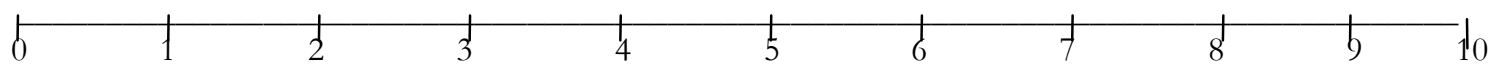

9. Commitment: Is interested and invests in development. Understands the nursing policy and philosophy of the institution searching and taking advantage of the opportunities that come from the practice field.

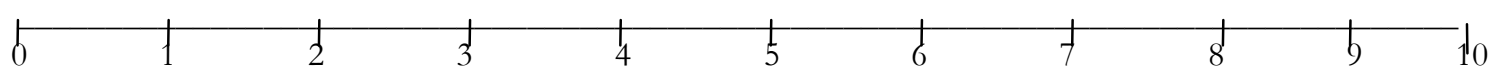

10. Case study: pertinence and relevance of the problem selected. Planning, analysis, and intervention assessment.

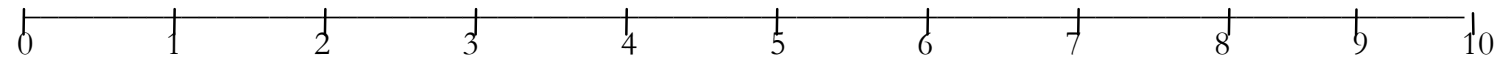

